Polynesia in Review: Issues and Events, I July 200 I to 30 June 2002

Reviews of American Sāmoa, French Polynesia, Niue, Sāmoa, Tokelau, and Tuvalu are not included in this issue.

\section{Cook Islands}

For the Cook Islands, the period July 200 I to June 2002 was dominated by continued population decline, unpopular political party switches by members of parliament, cabinet shuffles and reshuffles, dengue fever, flooding, ten-year high inflation, land controversies, and immigration concerns. Political events in the country's capital, Rarotonga, marked a year of major challenges for its democratically elected government, great political and reorganization disappointments, and a few guarded economic successes.

The country's two banks, Cook Islands Savings Bank and Cook Islands Development Bank, merged as the Bank of the Cook Islands (CIN, 2 July $200 \mathrm{I}, \mathrm{I})$, and welcomed its first customer on 4 August 200I. As the new bank became an important arm of government for many financial transactions, some public servants increasingly complained of being on the same annual salary of $\mathrm{NZ}$ \$I, 000 for ten years. They argued that disparities within the public service reflected a fundamentally unfair system. Cook Islanders generally observed that too much was being paid to heads of ministries, whose salaries ranged between $\mathrm{NZ} \$ 45,000$ and NZ\$80,000 a year. Public Service Commissioner Jonah Tisam received little support when he pointed out that no public servant was overpaid; rather, those on the lower scales were being underpaid (CIN, 3 July 200I, I). Considering that inflation in the small nation was hitting a ten-year high, government workers who were generally on a lower scale felt most of the pinch. The cost of a loaf of sliced white bread was reported as rising (in NZ dollars) from $\$ 2.80$ to $\$ 4.20$, and French bread sticks from $\$$ I.20 to $\$ 2.40$ (CIN, 9 Feb 2002, I). Economists predicted that prices would rise even further, while describing the government's B rating by Standard \& Poor as meaning that the country's economic outlook was fair (CIN, 8 Sept 200I, I).

Open criticism of the public service compensation system continued throughout the year and extended to the superannuation system, which needed much improvement. By contrast, the country's parliamentary superannuation system was well established and overgenerous despite a parliamentary select committee's report calling for an urgent overhaul of former parliamentarians' superannuation payments because of the cost to the country. The government matches the parliamentarians' contribution of io percent from salary, but payout eligibility occurs after only eight years of continued service. This contrasts starkly with the much longer service required in the public service or private sector. The parliamentarian scheme alone cost the government $\mathrm{NZ} \$ 525,000$ in the $200 \mathrm{I}-2002$ finan- 
cial year. Other costs reflected parliament and government's continued appointment of assistant ministers under the new, disguised title of "undersecretary." For a small country, there were clearly too many parliamentary representatives and too many cabinet ministers, and certainly there was no need for assistant ministers. Although the general public was convinced of this, politicians seemed oblivious to their concerns.

The public outcry about politicians fell on deaf ears. Indeed, cabinet even contemplated increasing the number of ministers to 9 , which meant that out of a full parliament of 25 members, I 8 (or 72 percent) of the House would be either ministers or assistant (undersecretary) ministers. Even the current 6 cabinet members $(48$ percent of the House) must be among the highest in the world relative to the size of the legislature and the population as a whole. Apparently the proposed change could not be justified without infringing on the responsibilities of senior administrative department heads.

Proposals such as this seem to the public to disguise crude bids for increased salaries and extensive travel privileges; free use of government vehicles, telephones, furnished houses; as well as free use of government laborers, and the opportunity to offer work opportunities to constituent supporters. The fact that most ministries were reported to have failed to file legally required reports to parliament during the year supported a general sense of their inefficiency and lack of accountability. Cook Islanders are also constantly reminded of the nation's debt of around NZ\$I2I.3 million, which will take at least twenty-five years to pay off (CIN, I7 Aug 200I, I). Much of that debt accumulated from the legacy of the multimillion-dollar Sheraton luxury hotel project-now frequently referred to as the Vaima'anga "on-again-off-again" project (CIN, 2 I Feb 2002, I).

A new NZ\$400,000 tugboat, Toa, was launched in July 200I, at the same time questions were being raised by the general public about government waste. Government spending for I999-2000 represented 4I percent of

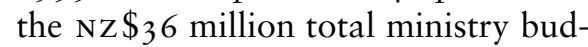
get. The I July 2000 to 30 June $200 \mathrm{I}$ period fared no better (CIN, 6 July 200I, I). Increased government spending was predicted to total $\mathrm{NZ} \$ 54$ million, with the total budget expected to exceed NZ\$75 million (CIN, 3 I July 200I, I). The Cook Islands Chamber of Commerce noted that government expenditure had increased by 20 percent over the past two years (CIN, I 3 April 2002, I). Ironically, some chamber members also expressed anger that marketing dollars for the tourism industry had been cut. Linked with tourism were proposed developmental projects, including alterations to the Rarotonga airport terminal expected to cost up to NZ\$9.5 million.

The largest industry, tourism, continued to maintain its prominent position during the year, despite the legacy of the September I Ith attacks in the United States. A national memorial on Maire Nui Drive for the September I Ith attack victims reflected the country's general support for the United States. However, there was a drop in US and European visitors, most coming through Los Angeles. Some visitors were stranded on Rarotonga by 
the US ban on flights, and more than 300 visitors later experienced the same thing after Canada 3000 grounded all its flights and later declared bankruptcy. Some 74,54I people still visited the Cook Islands in $200 \mathrm{I}$ compared to the record-breaking 72,994 in year 2000 (CIN, I4 Jan 2002, I). The target set by the Cook Islands Tourism Corporation for 2005 had already been broken by 2000 . Visitor counts were expected to continue to rise with the completion of new tourist accommodations, including the large Aitutaki Pacific luxury resort scheduled to open in October 2002. On the surface, the booming industry appeared to benefit local residents. However, many tourist-related work positions were filled by workers from overseas. The importation of labor was encouraged by some assistant ministers, who accused Cook Islanders leaving the islands of being just plain lazy-all 4,000-plus of them.

Local resident Professor Ron Crocombe suggested that Cook Islanders often leave because they lack confidence in the government (CIN, I 2 July 200I, I). The high cost of living in the Cook Islands, with prices more than people can afford, adds much to the incentive to move out. Although the government acknowledged a continuing huge decline (with the population estimated to have decreased to 13,900 from some i 8,000 a few years earlier), leaders still expressed other priorities. Cabinet even dropped a campaign designed to lure islanders home (CIN, 23 Feb 2002, I). The assistant minister declared that those who do not want to work in the country were fleeing the country to live off benefits in New Zealand, an explanation that ignores poor salary conditions in an increasingly expensive environment, the lack of effective unions for workers, and a tendency for national politicians to lash out at the media for criticizing official policy and action.

During 200I-2002 wide public concerns increased over the number of permanent residents being allowed into the country. Some foreigners have even been openly accused of coming into the Cook Islands with nothing in their pockets. "Like parasites they are sucking the small facilities that are available in our backs as resources for themselves," reflected MP Norman George (CIN, 25 Aug 200I, I). George also suggested that lax policies toward foreigners led to increased numbers of foreign investors operating in the Cook Islands. No safeguards exist for local businesses, and reduced opportunities tend to fuel out-migration. George favored revoking the right of the Cook Islands Development Investment Board to grant immigration permits, leaving that responsibility to the immigration officers alone. George also favored setting up a watchdog organization to protect jobs, businesses, and land rights for the people of the Cook Islands, to be called the Society for the Promotion and Advancement for the Cook Islands Employment and Business (CIN, I Sept 200I, I).

The once larger agriculture industry had now clearly slipped in earnings, although pawpaw, nono (or noni), maile, and other products continued as notable exports. New challenges to the industry during the year included a coconut moth that invaded coconut trees in Rarotonga, making the trees brown and tarnished. The government declared a biological war on the flat coconut moth, involving the use of bio-agents that are natural enemies 
of the moth (CIN, I9 July 200I, I). However, efforts to constrain the problem in Rarotonga seemed hopeless, and by June 2002 the moth had spread to the outer islands. The arrival of the Queensland fruit bat was also feared as a potential natural disaster that could wipe all fruit growing in the Cook Islands. Added to that was tropical storm Trina, which brought five days of floods and wind. The island of Mangaia was particularly hard hit by the storm, which wrecked the island's taro crop.

The pearl industry is now the third largest industry in the Cook Islands, with pearl farmers expecting a further boost in production. Although subject to quality control standards, internal competition, and climatic changes, the industry continued to do better than a steadily growing local fishing industry. Industry leaders are also becoming increasingly mindful of the rich potential offered by seabed mining resources within Cook Islands waters. However, as American Samoan politician Eni Faleomavaega Hunkin observed at the 7 th Pacific Islands Conference on Nature Conservation and Protected Areas held in the Cook Islands in 2002, seabed mining could be a future source of international conflict.

Political attention too often focused on the established offshore banking industry. The wall of secrecy surrounding these activities had its challenges too, and the government now regards loosening its secrecy laws as vital to the continuing success of the industry. Even with the proposed internal changes, the Cook Islands still remained on the Financial Action Task Force blacklist (CIN, I I Feb 2002, I).

Government activity in the inter- national arena showed some success. A Center for Development of Enterprise was established as part of European Union "antennae" to the Cook Islands. Although involving only a part-time position, this development represented Cook Islands' acceptance into African Caribbean Pacific membership in 2000 , after twenty years of lobbying. Project proposals by local Cook Islands organizations could now be processed, with an individual ceiling of $€_{\mathrm{I} 5}, 000$ or about $\mathrm{NZ} \$ 3,000,000$ per year (CIN, 5 July 200I, I). By I7 January 2002, the European Community Head of Delegation had presented his credentials to the Cook Islands Head of State, Queen's Representative Mr Fred Goodwin.

During the same period, Cook Islander Francis Topa-Apera was chosen to lead the region's Pacific Foundation for the Advancement of Women, and Rohan Ellis was selected to head the Pacific Islands Forum's Beijing office. New Zealand citizenship remained the single most important issue to the Cook Islands, and the practice of shared citizenship is expected to continue. An international conflict was avoided after an overzealous UN information officer, Angelique Doureihi, incorrectly named the Cook Islands as a shipment point for illegal drugs bound for Australia. The damaging allegation was distributed throughout the region via PACNEWS. When asked by the Cook Islands to clarify her accusation, she apologized and blamed the reporter on the radio program where the story was first aired (CIN, 2 March 2002, I).

The year 200I-2002 saw the reemergence of a controversy over an alternative cancer treatment facility 
established by Dr Milan Brych in the I970s. This time the issue involved the neglect of the graves of some former patients who came to the Cook Islands when Dr Brych was no longer able to practice in New Zealand (CIN, 6 July 200 I, I). Other health issues involved stinging criticism of the local national hospital staff and their treatment of a tourist. Nevertheless, visiting New Zealand Health Minister Annette King declared that the Cook Islands health service rivaled that of similarly populated areas in her country (CIN, I 4 Jan 2002, I). Such acclamations could not prevent the dengue fever that struck Rarotonga at the same time the island was hit by flooding. As cases increased, the Ministry of Health urged a major cleanup to fight the mosquitoes that spread dengue. A few tourists contract the disease, and in February 2002 differences developed between the minister of health and the mayor of Mangaia, who wanted to isolate his island (about I I 0 miles south of Rarotonga) to stop the fever from coming in. By the beginning of March dengue fever had reached Manihiki Atoll, an island much further from Rarotonga.

The national hospital again came to the fore as the parents of the late John Atuatika queried the death of their son and searched for his medical records at the Health Ministry (CIN, 6 March 2002, I). Atuatika's body was exhumed for a postmortem, the first time this had occurred in the Cook Islands in the context of an inquest. A proposal by Aucklandbased Diatranz, Ltd., to conduct tests on humans using pig cells also received international attention and concern (CIN, 4 March 2002, I).
Meanwhile Health Secretary Tupu Araiti successfully lobbied for a law encouraging cremations, claiming that this was in line with a public move away from the practice of burials.

The Cook Islands political leadership crisis remerged in the middle of July 200I with rumors of new coalitions, MP realignments, and leaked reports of conflicts in cabinet. In theory the three main political parties were the Cook Islands Party (CIP), Democratic Alliance Party (DAP), and New Alliance Party (NAP). In reality, party membership was more for election purposes, and individual members of parliament felt free to shift at will. The New Alliance Party and the Democratic Alliance Party had merged at one point, but when dissatisfied former DAP members wanted to return to their old party, they realized that they had lost the name legally and had to consider returning to the Democratic Party. Even though the Westminster parliamentary system was proving inadequate for the Cook Islands, sitting members were not inclined to make any real changes, a disappointment to many electors. Subsequently there was much public apathy when the Cook Islands News predicted a change of government with a new coalition between $\mathrm{Dr}$ Robert Woonton and Sir Geoffrey Henry (CIN, 2I July 200I, I). This was to be the fourth coalition since the 1992 general election.

Apathy toward political leadership extended to parliament as an institution when the normally stable position of parliamentary speaker became a political maneuvering tool. Longtime senior public servant Joe Cafferey turned down the request to serve as 
Speaker of the House for one day and then resign to pave the way for Dr Pupuke Robati (CIN, 23 July 200I, I). The process eventually took place with Harmon Pou Arere substituting for Cafferey. "Mickey Mouse," "political farce," "comical exercise," and "stupidity" were some of the comments directed at these government actions. The cost to taxpayers for the two-and-a-half hours of Harmon Pou's work was estimated to be more than NZ\$6,000 (CIN, I 8 Aug 200I, I).

Almost immediately after the Speaker fiasco, Prime Minister Dr Terepai Maoate sacked Deputy Prime Minister Norman George and took over all portfolios (CIN, 27 July 200I, I). Unfortunately the timing of the sacking loomed over the national constitutional celebrations known as Maire Maeva Nui, disappointing many members of the public. Curiously, though, a quick street survey by the Cook Islands News suggested that few respondents were sympathetic to George's predicament. With Mr George sacked, Dr Maoate confirmed Dr Robert Woonton as his new deputy prime minister. Woonton warned that one or two senior officials in the prime minister's department were not carrying out government policy, and that their actions could lead to a reshuffle in the government (CIN, 4 July 200I, I). He also suggested that "Promises of political reform and transparency were not being lived up to," a statement rebuffed by Prime Minister Maoate (CIN, 5 July 200I, I). Rumors of back-seat maneuvers continued as overseas member of parliament Dr Joe Williams declared that he had been ordered to stop a coup (CIN, I I Aug 200I, I). Prime Minister
Maoate added to the perplexity when he labeled the previous two years as confusing, a reference to attempts to transfer central government functions to the outer islands (CIN, I2 Sept $200 \mathrm{I}, \mathrm{I})$. He was alluding to a growing management and accountability conflict between local and national administration. After a five-month break, parliament finally met, but their first session lasted only ninety minutes (CIN, 2 Feb 2002, I). Not long after I 2 Feb 2002, the deputy prime minister ousted his boss Dr Maoate as prime minister. Within ten days of his administration taking office, new Prime Minister Dr Robert Woonton promised to remove import levies, introduce a health insurance scheme, pursue full UN membership, and review benefits and basic wages (CIN, I3 Feb 2002, I). New government ministers were sworn in $\mathrm{I} 3$ February 2002, and the Cook Islands had their fourth government since the I999 general elections. Continued apathy or increased opposition seems likely as the country approaches the general elections in two years' time.

JON TIKIVANOTAU M JONASSEN

\section{Reference}

CIN, Cook Islands News. Rarotonga.

Daily.

\section{Hawaitan Issues}

On I7 January I 893, the monarchy of Hawai'i was deposed by a group who "represented the American and European sugar planters, descendents of missionaries and financiers" (US Public Law I03-I 50). With the aid 
of the United States minister, John L Stevens, and US military forces, they were able to deliver Hawai' $i$ into the hands of the US federal government. In a case of historical déjà vu, it seems the same adversaries from a century ago have now been reincarnated and are attacking what is left of native rights in Hawai'i.

Since the I970s there has been slow, deliberate progress in raising public awareness of Hawai'i's unique history, culminating in the "Apology Bill” (US Public Law I03-I 50) of I993, a formal apology by the US government to the Hawaiian people. However, a shift toward a more conservative political climate under the new Bush administration, beginning in November 200I, and the hyperpatriotism inspired by September I Ith, have fueled vigorous attacks on native Hawaiian rights and entitlements.

These renewed attacks have prompted leaders of the Hawaiian independence movement to stress the need for a stable, protected path toward self-determination.

The Office of Hawaiian Affairs (OHA) and the Department of Hawaiian Homelands (DHHL) are two of the most highly targeted agencies run by the State of Hawai'i. Since its inception in 1978 , the Office of Hawaiian Affairs has served as a liaison agency between the native Hawaiian people and the State of Hawai'i. In that capacity, the office manages Hawaiian trust assets and entitlements, such as land and money, and programs for housing and education. As the beneficiaries of this trust, those of Hawaiian ancestry alone elect the OHA trustees and have a say in issues relevant to the trust. The Department of Hawai- ian Homelands was established as part of the Hawaiian Homes Commission Act in I92 I, which set aside 200,000 acres of land for native Hawaiian homesteading. Both of these agencies exist in an effort to address the needs and concerns of the Hawaiian people who suffered the loss of a nation.

Prior to the conservative shift in the US federal government, the stage was already being set by local challenges to the Office of Hawaiian Affairs. In I996, Harold "Freddy" Rice, a nonHawaiian rancher and businessman, was turned away after requesting a ballot to vote in оHA elections. On this refusal, Rice sought legal recourse, accusing the state government of violating his civil rights. Claiming that the Hawaiians-only policy reserved for the Office of Hawaiian Affairs by the state government was racist, he sought its abolishment. The infamous case quickly went up the judicial hierarchy and was finally heard by the US Supreme Court in early 2000. This time the justices of the Supreme Court agreed with Rice and his legal team, and in February 2000, the US Supreme Court opened voting in OHA elections to non-Hawaiians. Fortunately, the court confined its ruling to the voting practices of the State of Hawai'i and did not make any further determinations regarding native entitlements. However, any sense of relief over the narrow ruling was tinged with feelings of dread as the case set a dangerous precedent.

Immediately following the Rice $v$ Cayetano ruling various anti-native rights groups filed lawsuits challenging the very existence of the Office of Hawaiian Affairs, the Department of 
Hawaiian Homelands, and more broadly, any programs meant to assist Hawaiians. John Carroll, Patrick Barrett, and most recently, Earl Arakaki are among the plaintiffs rotating the lead on lawsuits threatening native Hawaiian agencies and entitlements.

While these lawsuits originate outside the Hawaiian community, the July 2002 admission of a non-Hawaiian student to the Kamehameha Schools, a private institution that offers quality education to Hawaiian children, seemed to relocate the threat to the boardroom of a Hawaiian trust institution. Citing legal challenges to the school's tax-exempt status as a religious institution, and its policy of preference for Hawaiian children, the Kamehameha trustees admitted a non-Hawaiian student to the Maui campus, despite a waiting list of dozens of Hawaiian children. The Hawaiian community, which sees the Kamehameha Schools as one of the few remaining, distinctly Hawaiian strongholds, was outraged by the decision. The demands of alumni, students, and many others in the Hawaiian community ranged from requests for explanations and apologies to outright calls for trustees' resignations. Seeking a solution would be simpler if the trustees' decision was seen as an isolated incident, but it is not. Rather, it is one more symptom of a larger problem of native entitlements sliding away.

In the midst of this rapidly eroding landscape, enter US Senator Daniel Akaka and his bill for federal recognition of a "Hawaiian Governing Entity." Introduced in I999, this was an immediate response to the Rice $v$ Cayetano case and the need to rectify and clarify the relationship between the US government and the Hawaiian people, as well as to protect the one hundred or more federally funded programs and agencies that assist Hawaiians. It was meant to provide a "process for the recognition by the United States of the Native Hawaiian Governing Entity" and to create "an avenue for federal recognition of a Native Hawaiian Government parallel to the existing petition process for Native Americans" (Kanehe 200I, 863 ). Heralded as the "most viable antidote to the feared unraveling of entitlements for Hawaiians" (Boyd 2000, 8), the "Akaka bill," as it has come to be known, may turn out to be nothing more than a Band-Aid on a gushing head wound. The controversial bill has gone through several drafts and amendments, the latest of which is currently stalled in US Congress.

Passage of the bill would establish a relationship between a Native Hawaiian Governing Entity and the US government by establishing an office within the US Department of the Interior to focus on native Hawaiian issues and to serve as a liaison agency between native Hawaiians and the federal government, and establishing an interagency coordinating group to be composed of representatives of the federal agencies that administer programs and implement policies impacting native Hawaiians (US Senate 200I).

Proponents of the bill also regard it as a stepping-stone toward independence. As efforts progress, they hope the legislation would eventually lead to secession from the United States. The Native Alaskans recently received 
federal recognition from the United States and are encouraging native Hawaiians to pursue the recognition avenue. While Alaskan recognition has not been ideal, it has nevertheless preserved their entitlements and provided a platform for further development of their self-determination.

While sponsors of the Akaka bill stress its defensive assets, opponents of the bill believe that we must be on the offensive and forcefully pursue international avenues. They view the Akaka bill as an "impediment to achieving independent status" under international law. In the eyes of a colonizing government, it may very well be seen as a settlement and cripple all other efforts in the international arena. While the bill may afford temporary legal protection for native programs and entitlements, they say the price is too high. By being recognized as Native Americans by the US government, the Kānaka Maoli risk giving up their identity and extinguishing any chance of independence through the United Nation's decolonization process. Many advocates of Hawaiian independence remind us that the Kingdom of Hawai'i still exists despite foreign occupation. Thus, as an internal US legislation, the Akaka bill has no bearing on kingdom law.

A second category of opponents to the Akaka bill includes those who made the measure necessary. Rice, Arakaki, and other members of anti-affirmative action groups, such as Campaign for a Color-Blind America, disapprove of any native entitlements and dismiss them as racist. Despite history, these groups equate the Office of Hawaiian Affairs, the Kamehameha Schools, and actions like the Akaka bill with "apartheid" and "ethnic cleansing" and claim that no reparations are owed to the Hawaiian people.

It is ironic that the Rice $v$ Cayetano case consolidated the efforts of various sovereignty advocates, while the Akaka bill has effectively divided Hawaiians. The silver lining in the cloud threatening to eclipse native Hawaiian entitlements, however, is the generation of political discussions and choices on a scale larger than ever before. As local legal challenges to agencies such as the Office of Hawaiian Affairs, Department of Hawaiian Homelands, and the Kamehameha Schools increase, the federal recognition bill is more and more tempting to opponents despite its shortfalls. The Alaskan natives have reiterated their solicitation of federal recognition, saying that the first bill passed regarding their recognition was not ideal either, but it provided semiautonomy over their lands and assets as well as protection from opponents to native rights. So, the Kānaka Maoli of Hawai'i now stand at another critical crossroad in Hawaiian history: to support or oppose federal recognition in the face of multiplying legal attacks.

Whether we make the choice to extol the protective properties of the Akaka bill or disregard it for its wavering loyalties, the goal remains the same. We must proceed with assertive wisdom and use every resource to pin down self-determination in spite of the efforts of our adversaries in the US legal system, international arenas, and hedonistic Hollywood.

There is no doubt that colonialism is alive and well in Hawai'i. Lorrin 
Thurston, John Stevens, and

W O Smith, the architects of the overthrow of the Kingdom of Hawai'i, have been reincarnated as Harold Rice, Patrick Barrett, and Earl Arakaki. The Kamehameha trustees have disappointed the people who look to them for leadership and passively yielded to the demands of our adversaries, much like the cabinet that abandoned our last queen, Lili'uokalani, in her hour of need. As I write this, America is celebrating its Independence Day (July 4). Will the Hawaiian people once again be able to celebrate their Independence Day? Or, will history repeat itself and relinquish the Hawaiian Nation to a footnote in history?

TRACIE KU'UIPO CUMMINGS

\section{References}

Boyd, Manu. 2000. Speeches, Debate, History and Song among Sovereign Sunday Highlights. Ka Wai Ola o OHA I9 (2 [February]): 8. Honolulu: Office of Hawaiian Affairs.

Kanehe, Le'a Malia. 200I. The Akaka Bill: The Native Hawaiian Race for Federal Recognition. University of Hawai' $i$ Law Review 23 (2 [Summer]): 857-906.

US Senate. 200I. Native Hawaiian Recognition Bill. I07th Congress, Ist session, S 746 Rs (6 April).

\section{MĀori Issues}

In a year dominated by the approaching general election, Māori have watched the government, including Māori members of parliament, steer away from any public debate on Māori issues. In recent years, Māori members have come under sustained attack from the conservative opposition and the mainstream media whenever they have attempted to articulate Māori aspirations for greater control over their lives. Calls from non-Māori lending support to those aspirations generally receive little or no media coverage. So on Waitangi Day in February 2002, when Pākehā groups at Waitangi, including the Green Party, publicly stated their support for Māori sovereignty, it went unreported in mainstream media. Several days later it was partially reported when the Green's leader signaled a softening of the stance on Māori sovereignty because "many people find the term very frightening." Yet even the Ministry for Māori Development, Te Puni Kōkiri, advocated restructuring local government to ensure that Māori have greater control over their own affairs. In the final weeks before the July 2002 election, as right-wing parties were attacking the Treaty of Waitangi and promoting a cut-off date for all Māori claims against the Crown, the largest mainstream newspaper ran a story on Māori views of Māori sovereignty. It had to admit that a significant number of Māori interviewed wanted Māori sovereignty recognized, yet the article concentrated on reporting Māori giving reasons for why it should not be recognized.

Mainstream media coverage of Māori issues has continued to be a matter of concern on several occasions in the past year. Claims that the media were Māori bashing surfaced on several occasions. A television documentary on the "Treaty Industry" interviewed a disgruntled historian and two disaffected former employees of the Crown Forestry Rental Trust, a 
body that administers many millions of dollars of rental paid on Crownowned forests, and allocates some of its income towards the research and settlement of Māori claims to those forests. The trust has been under investigation by the Māori Affairs select committee for corruption. The television program sensationalized an alleged "Māori mafia" and attempted to blame Māori for the parlous state of the settlements. Of the 908 claims registered with the Waitangi Tribunal over the past twenty-six years, fewer than 20 have resulted in any land being returned to the claimants or compensation being paid out. Furthermore, not a single claimant group has received all the land and compensation they are entitled to. In the past year the Labour-led coalition government has partially settled just one claim, that of Ngati Tama in the Taranaki region-where, the tribunal stated in its 1996 report, Māori had suffered a holocaust. Ngati Tama lost more than 30,000 hectares. The settlement returns just I, 870 hectares and I 4.5 million dollars. The three other settlements achieved under the present government have been similarly mean-spirited.

Yet the "Treaty Industry" television program made no mention of the real reasons for the chronically slow and inadequate process of treaty claims settlement. The main reason is that every government in power over the past decade has refused to take any Māori advice on the need to radically reformulate its unfair and unjust settlement policy. Then there is the ongoing underfunding of the Waitangi Tribunal. There is also the pivotal role of the "experts" in the industry - the lawyers, historians, and government bureaucrats who seem content to prolong the process and charge exorbitant fees for as long as they can. The overwhelming majority of these people are non-Māori. Despite its lack of funding, the Waitangi Tribunal has intervened to try to speed up its hearings and reporting process, fast-tracking the Gisborne district hearings through in seven months in contrast to others that have taken more than four years.

The media coverage of the kidnapping of the eight-month-old daughter of a lawyer and a High Court judge, both of whom are Māori, caused further consternation. The fact that the child had been adopted from within the couple's extended family according to Māori custom was incomprehensible to mainstream media. Several newspapers tried to imply that Māori were somehow to blame for the kidnapping, despite Māori protestations to the contrary. Yet when the baby was found and the kidnapper arrested and sent to jail for eleven years, there was very little discussion of the fact that he was Pākehā and that his sole motivation for the kidnapping was money.

Māori views of the bombing of the World Trade Center in New York on September I Ith were also ignored until the initial furor began to die down. While Māori were appalled at the incident, they were not surprised. Māori radio stations interviewed Māori elders from around the country, many of them ex-servicemen, shortly after the bombing. All of the elders expressed views that the United States could not keep attacking and making war on other nations without expecting some form of retaliation. It was several days before similar views started to surface in the mainstream 
media, and the Green Party went on record as opposing New Zealand troops being sent to Afghanistan.

In the 2000-200I reporting period, the country's largest newspaper had run a campaign against Tainui. This year it was the turn of Māori television to be targeted, with the New Zealand Herald listing no fewer than eighty articles on its website (the same number listed for Tainui last year). Criticism of Māori television has been going on for more than six years, as mainstream media backed by government officials ignore Court of Appeal rulings and battle to keep Māori out of the industry. When the chairman of the Māori channel's board attacked the media for Māori bashing in April, they retaliated by closely scrutinizing all the workings of the channel. When they discovered that the Canadian chief executive officer had falsified his qualifications, the number of articles per day attacking Māori television peaked. The day after the board sacked the officer, ten articles, including an editorial, ran in the New Zealand Herald. The media appeared to be rather stunned, however, when the officer was subsequently jailed for six months and denied bail, a punishment that legal experts saw as fitting the crime. Then the Herald was silenced completely by the appointment in May of an interim chief executive officer, who is one of the very few Māori millionaires and a very experienced businessman. He refused to speak to any mainstream media and in interviews with Māori media said he was not interested in anything that the mainstream media had to say.

The one Māori member of parliament prepared to take on the mainstream media, Tariana Turia, did so in
March 2002, referring to the media as "hysterical, hostile and ill-informed" over her reference to a Māori holocaust in 2000 . She predicted that the media would attack her during the campaign for the 2002 general elections. Her prediction appears to have been sufficient to stop them from doing so. Turia traveled around the country attending many Māori gatherings (bui), including those organized in different tribal regions for ministers of the Crown to meet Māori in their own territories. Although the media attended such events, they were not interested in what Māori were saying there. Requests to the prime minister during these hui to be more outspoken in support of Māori drew the response that whenever she did say such things to the media, they did not report them. In the main she considered that the media were only looking for incidents that would allow them to report Māori negatively.

Yet there were also the occasional bright patches. In February, the film of the Māori-language version of Shakespeare's The Merchant of Venice played to rapturous audiences throughout the country. Despite the historic and cultural importance of the piece, in particular because of the endangered state of the Māori language, it received minimal media coverage. Yet a four-star rating and an excellent review from a Pākehā film critic appeared in the New Zealand Herald. Massey University later conferred an honorary doctorate on the producer, Don Selwyn, for his many years of stage, television, and film work, and his training and mentoring of young talent.

And then in May, a tribal radio station topped the ratings to become 
Auckland's most-preferred radio station. Ngati Whatua's MAI FM caters to Māori and Pacific Islander youth and features rap music, rhythm and blues, jazz, hip-hop, and more recently, New Zealand-produced music. While its popularity had displaced mainstream radio stations in the polls, it follows naturally from the fact that among the population in Auckland who are twenty-five years of age and under, 20 percent are Pacific Islanders and 16 percent are Māori. That, and the fact that a survey of MAI FM listeners indicates that they don't watch television because it does not reflect them. Likewise mainstream advertising.

Although the prime minister claimed to be supportive of Māori, her apologies to non-Māori sectors of the New Zealand society drew some bitter responses from Māori. In February 2002 she apologized to the Chinese community who were forced to pay a poll tax from I 88 I until I 944 . Then in June she apologized to the Samoan community for the New Zealand government's role in allowing the introduction of a devastating influenza epidemic in I9I 8 and the gunning down of Mau protestors in I929. Yet Māori have yet to receive any overall apology for their on-going ill treatment at the hands of successive colonial governments and the numerous breaches of the Treaty of Waitangi perpetrated against them. Māori commentators noted that while the prime minister was apologizing to others, Māori on the East Coast were protesting to stop their lands being sold to American developers, Māori elders in Northland were being arrested for attempting to defend their sacred sites, the police in Whāngarei were being repeatedly criticized by the courts for their treatment of Māori youth, the chief justice sent a Waitara policeman to the High Court to defend a charge of murdering a young Māori student, Raglan police were criticized by a district court judge for chasing two Māori onto a marae and scuffling with them inside the sacred meeting house, and a conviction for not giving a name and address to a policeman was overturned by the High Court when it ruled that it is not an offense to answer a policeman in Māori, one of the two official languages of New Zealand.

Yet the government is well aware that Māori receive unfair treatment. Apart from its own Closing the Gaps reports highlighting the huge and growing disparities between Māori and non-Māori achievement, its report on the tertiary education sector has resulted in tertiary institutions being warned that unless the recruitment, retention, and completion rates for Māori improve markedly, they will be stripped of some of their government funding. Yet local government reforms did almost nothing to address the lack of roading, water supply, electricity, housing, and basic living standards for many rural Māori communities. Apologies and remedies for all of these and many other indignities still suffered by Māori are long overdue.

It is doubtful that the answer to Māori difficulties lies within the existing parliamentary system. In June the prime minister announced that the country would go to a general election four months early, at the end of July. The main election issues for Māori were treaty settlements, education, and housing. Genetic modifica- 
tion of crops is also an issue, with Māori largely opposed to it. The apparent lack of performance of many Māori members of parliament was another issue. One commentator noted that of the sixteen Māori members in the last parliament, fewer than six could be relied on to advocate for Māori and only one, Tariana Turia, was prepared to fight publicly in support of Māori issues. The poor performance was not unexpected, given the severe attacks from both the media and conservative opposition parties on any outspoken Māori members and the fact that party loyalties have effectively prevented their acting as a single bloc.

Yet the July 2002 elections saw a record number of 20 Māori members in a parliament of $\mathrm{I} 20$, with I I representing their own electorates and the rest as list members for their parties. But none of these were independents. All 7 Māori electorate seats remained with Labour, with the Labour Māori caucus at a record Io members within the full Labour caucus of 52 . Yet despite the strong Māori numbers, shortly after the elections the Mãori caucus indicated that it was requesting just three ministerial appointments inside cabinet and three outside cabinet in what it appears will be a Labour-led minority government.

Of the remaining parties, the traditional mainstream conservative party, National, returned only 27 members, with their vote dissipated among right-wing minor parties. Only 2 of their members are Māori. Of the other three right-wing parties represented in the house, New Zealand First gained I 3 seats, while АCT and United Futures each gained 9. The New
Zealand First party is led by a Māori, the charismatic Winston Peters, and despite a general impression that he is Māori bashing, 6 of his 13 members are Māori. Аст has I Māori member, while United Futures has none. The left-leaning Green Party gained only 8 seats, I of which went to a Māori. The Progressive Coalition has 2 members, neither of whom are Māori. At the time of writing, Labour had entered negotiations with both the Greens and United Future about the composition of the next government.

MARGARET MUTU

\section{TongA}

The triennial general election was held again in March 2002. Democracy supporters claimed that their win of seven of the nine People's Representatives' seats was a conclusive victory for the movement throughout the kingdom. Other observers did not find the outcome so clear-cut.

The Tonga Human Rights and Democracy Movement (THRDM), which was formed in 1998 to replace the Pro-Democracy Movement, did not formally field candidates for the election because, as it claims to be merely a mass movement that seeks political change, the conditions under which it receives funding from various overseas agencies prevent it from doing so (MT, May 2002, I2-I6). After the outcome, however, the movement was quick to claim a win. The most vocal of its representatives'Akilisi Pohiva, Dr Feleti Sevele, and 'Isileli Pulu, who became the Tongatapu No I, No 2, and No 3 People's Representatives respectively-claimed 
that the result represented a mandate from the people to institute the government restructure that had formed the basis of their campaign. This idea, namely, that all thirty members of the Legislative Assembly (from which the monarch would still appoint his cabinet ministers) be elected by common roll, has been previously aired, discussed, and defeated in parliament in I992. Although the idea appeared better understood by the electorate than previously, especially in Tongatapu, there is little evidence that the idea was the primary factor that swayed the voters there or in the other island groups. Indeed, progovernment supporters (notably the minister for police, the Honourable Clive Edwards, and Tuisoso, the editor of the government owned and controlled newspaper, Kalonikali [The Tonga Chronicle]) disagreed, and argued that the results merely reflected the usual contest for votes between individuals to see who would enter parliament. They further asserted that it was conducted in the older-style fashion of personalized politics, rather than as an ideological battle over ideas that remain poorly understood by the mass of people. However, these arguments prove rather equivocal, as in several cases the personalized issues tended to coincide with principles.

Three commoners' seats are allocated for Tongatapu, two for each of the Ha'apai and Vava'u groups, and one each for the Niuas and 'Eua. If the result was a nationwide mandate for change, however, it is noteworthy that the voter turnout was the lowest ( 44.3 percent) in Tongatapu and only 49 percent in the country overall. The smaller islands had higher turnouts: Ha'apai and Vava'u each had 53 percent, and the Niuas and 'Eua had 69 percent and 56 percent respectively. While it is always more difficult to say why people did not vote rather than why they did, the Tongatapu reaction suggests that either a high proportion of registered voters were overseas, or they preferred not to vote because of disenchantment with the candidates or perhaps the whole idea of politics.

It should be noted also that the lead-up to the elections was marked by several disconcerting events. One of the most unprecedented was New Zealand Minister of Foreign Affairs Phil Goff's attacks on the Tongan government's credibility. He suggested in a series of remarks that the level of corruption and the failure to uphold the constitutional rights of its citizens, along with the fact that no major political change was in the offing, might affect the future level of New Zealand aid. The Tongan government regarded this interference in its internal affairs as an impingement on the nation's sovereignty and an attempt to bias the outcome of the forthcoming election. There was also some suggestion in the local press that Goff's remarks were prompted by Pohiva's ongoing efforts to engage the sympathies and actions of larger neighboring Pacific Rim countries for his political ends (TC, 9 March 2002, I).

Another matter that arose was the amount and source of the king's private funds. The issue came closely on the heels of the Tonga Trust debacle, in which Us\$20 million appeared to have gone missing as a result of a series of dubious investment maneuvers (or a long-term scam) on the part 
of the fund's advisor, J D Bognadoff. Bognadoff is a US citizen who first claimed the king's attention in the role of court jester. The trust's lack of proper administration by the two cabinet ministers placed in charge of itthe Honourable K T Fakafanua (the former minister of finance) and the Honourable $\mathrm{T}$ Tupou (the former deputy prime minister, attorney general, and minister of justice)-resulted in their resignations from office in September 200I. The loss of the money invested with a US-based company, Millennium Assets Management, was confirmed in a report to the Tongan government on 7 June 2002, following ten months of speculation about its fate. After investigations in the United States by Auditor General Pohiva Tu'i'ionetoa, the trustees have instructed a team of San Francisco lawyers to commence legal proceedings against Bognadoff and two others. The trust has claims against six companies alleged to have been involved in the transference of the money, some of which relate to failure to pay or default on payment of a promissory note, fraud, conspiracy, aiding and abetting fraud, negligent misrepresentation, material misrepresentation, and fraudulent conversion (TC, I3 June 2002, I7). It now remains to be seen who, if anyone, laughs over the loss to the kingdom of $\mathrm{T} \$ 50$ million.

While this was going on, Ko $e$ Kelea, the radical newssheet now edited by Pohiva's son, published a letter allegedly written by a former palace secretary stating that the king had a personal fortune of us $\$ 350$ million. In an interview, the king freely admitted that he has a bank account in Hawai' $i$ in which he invests the proceeds from his vanilla production but that the amount is not near the one quoted. The letter involved an allegedly forged signature, however, and the week before the election, police raided Pohiva's home and the THRDM office and confiscated a hard disk on which a copy of the letter was allegedly found. Some people felt that this find might promote a conservative vote, but in the event, the harsh treatment meted out to Pohiva, his son and daughter, and 'Isisleli Pulu, a THRDM office-bearer, appears to have swung voters toward the movement. In another landmark development following the election, Pohiva and his son were charged with sedition, fraud, and defamation, and Pulu with fraud. If these two members of parliament are convicted of criminal charges later this year, they stand to lose their seats.

In the Tongatapu elections, I4,734 people actually voted from a roll of 33,232 people registered. Of these, Pohiva romped home with 9,437 votes, scoring electoral victories at all polling stations, to return as the Tongatapu No I People's Representative as he has for the last twelve of the fifteen years since he was first elected to parliament in 1987. Dr Fred Sevele was returned for a second term as the Tongatapu No 2 People's Representative with 8,498 votes, and newcomer Pulu came into the No 3 place with 5,500 votes. In Ha'apai, a democracy supporter, Teisina Fuko, was ousted, and newcomer Fineasi Funaki became the No I People's Representative. The longtime THRDM parliamentarian, 'Uliti Uata, came back in the No 2 $\mathrm{Ha}$ apai position. In the Niuas, a reputed THRDM supporter, Sione 
Haukinima, was newly elected, and in 'Eua, another THRDM supporter, Sunia Fili, was returned to parliament. Vava'u, however, voted in two newcomers who oppose the Tonga Human Rights and Democracy Movement, with Trevor Guttenbeil and 'Etuate Lavulavu taking the No I and No 2 People's Representatives' seats respectively. Lavulavu has remarked that the monarchical form of government was ordained by God for Tonga, which goes some way toward explaining why it might prove difficult for Tonga to transform itself into a western-style democracy.

Perhaps the only way to test Pohiva's and Sevele's claim that people voted overwhelmingly for their proposed government restructure is to conduct a referendum on the issue. But this would have to be carried out by the government because the cost is beyond the means of the Tonga Human Rights and Democracy Movement. It would also be difficult to work out what questions to put to the people.

As matters stand, it is also difficult to separate ideological from personalized issues in the case of the more radical supporters. All commentators agree that people across the social spectrum vote for Pohiva because he leaks government business to the people. There is a degree of corruption, nepotism, and cronyism in middlelevel management that many government employees resent but feel powerless to address. Also, although the Tongan people remain loyal to their monarch, many people were privately incensed at his remark that his children have the same rights as everyone else in the country to build up their business interests. This fails to acknowledge the extreme social and cultural advantages they possess. In addition, they have picked the plum opportunities that rely on common property rights of all citizens: through her company, Tongasat, the Princess Royal controls the ownership of Tonga's orbital slots, and through his company, Shoreline, the Crown Prince now has a monopoly on the generation and distribution of Tonga's power supply. Through a fully owned subsidiary company, Tonfon, the Crown Prince also expects shortly to introduce wireless technology to compete with the existing government-owned Tonga Telecommunications Corporation. These moves indicate to ordinary people how the most privileged cash in on their country's common heritage and resources. They rely on 'Akilisi to give vent to their concerns in parliament, and to continue his tireless fight for public accountability and transparency. Sevele is a smart, educated, and successful businessman who, it is hoped, might improve people's livelihoods through support of privatesector development and the removal of the government's heavy hand over much business enterprise. Pulu might have received a sympathy vote over his police detention in regard to the alleged forged letter, and might also have gained from the lack of a strong opposition figure. 'Esau Namoa, the previous Tongatapu No 3 People's Representative and a popular young businessman, was disqualified from the election for not paying a government-imposed fine.

In Ha'apai, it is hard to distinguish the ideological THRDM element from the fact that both of the successful 
candidates are also well known as "helping men." Funaki, for example, had distributed school supplies to the tiny atolls that make up the middle group for a good two years before the election, and when Cyclone Waka struck in February 2002, he was instrumental in getting utilities restored and relief supplies sent to stricken households. Uata has always gained local support because he runs a fleet of interisland cargo vessels and thus provides a service to the community. In the Niuas, the strength of Haukinima's loyalty to the Tonga Human Rights and Democracy Movement is untested, while Fili for 'Eua, like others, at times wavers in loyalty to the movement's line according to political interest.

In sum, the mandate for government change is not as clear among the island groups as the Tongatapu representatives make out. Many people believe that no change at all will result, and even fervent supporters such as Futa Helu admit that the Tongatapu representatives will lead the way towards reform in the next three years, and that the other pro-democratic People's Representatives will follow them (Taumu'a Lelei, April 2002, 22-23). This is far from the claim that all seven THRDM supporters among the nine People's Representatives share the same degree of commitment to its ideals and goals. Thus, it is also too soon to claim a victory for democracy. In advocating the thirty-elected-member legislature, the Tonga Human Rights and Democracy Movement, in addition to accountability and transparency, is valuably advancing another democratic theme -namely, the greater representation of commoners in parliamentary decision making. Even if these aspects of good governance were advanced under the rubric of democratic reform, however, it would be wrong to mistake them for a step toward full representative democracy.

Despite the cries from the hustings in March, many people in Tonga still believe fundamental changes in politics, as in other social and cultural affairs, will emanate from the top, that is, from the government headed by the reigning monarch. On 9 August 200I, the principles of accountability and transparency appeared to have been wonderfully promoted when the prime minister announced the appointment of a commissioner of public relations to hear cases of abuse and misappropriation of power. The initiative received the highest praise from the People's Representatives. Teisina Fuko, the member for Ha'apai, for example, raved that "HRH the prime minister's ready agreement for the [appointment] demonstrates his strong support for the public to be aware of what Government does.... This is an exceptional achievement in our attempt to bring about better performance and more honesty in Government" (TC, 23 August 200I, 5). Since then, nothing more has been reported of the commissioner's activities. In another move, the government, with the help of a loan from the Asian Development Bank, has recently begun to reduce and restructure the civil service. Top-level meetings have been held, but members of the public have not been invited as participants or observers. Once more, the well-meaning but extremely paternalistic attitude that "government knows best" has pre- 
vailed. In the absence of facts, rumors abound with regard to the way the downsizing of the public service will take place, and many civil servants are at present restless and distressed, as they are unsure of their future and remain in the dark about the circumstances of their employment.

KERRY JAMES

\section{References}

MT, Matangi Tonga. Quarterly.

Nuku'alofa.

TC, Kalonikali, The Tonga Chronicle. Government weekly. Nuku'alofa.

Taumu'a Lelei. Roman Catholic monthly. Nuku'alofa.

\section{WALlis AND FUTUNA}

On 29 November 200I, French Overseas Secretary of State Christian Paul went to Wallis, where he declared: "I intend that the assistance of France shall not slacken." He confirmed the future opening of a vocational training center and the future implementation of a statute for members of parliament. He proposed the creation of a development council made up of all the local decision makers. In December, it was Didier Quentin, overseas secretary-general of the Rassemblement pour la République (RPR), and Pierre Frogier, president of the government of New Caledonia (of the party, Rassemblement pour La Calédonie dans la République [RPCR]), who went to Wallis to take their turn in preparing for the upcoming elections. The signing of the special agreement between the French Overseas Territory of Wallis and Futuna and the French Overseas Country of New Caledonia was once again postponed. In the meantime a guidance document on economic development was signed in Paris on 22 January 2002 between the state and the territory in the presence of customary leaders. This document was to be followed by a program contract along with a significant financial initiative.

The year 2002 was significant on the electoral level. First, the election in a single ballot of the twenty territorial advisers took place on ıo March. Thirty-two lists, bringing together a total of I 34 candidates, were submitted to 9,353 voters. Of those eligible, 82.7 percent voted. Spoiled ballot papers accounted for 0.75 percent, and 9.8 percent were proxy votes. The elections yielded a right-wing majority affiliated to the national RPR party. On 26 March, Patalione Kanimoa was reelected president of the territorial parliament by 12 votes to 7 , with one member absent for health reasons. The opposition unified for the election of the committee of the territorial parliament, in spite of the fact that it included as many right-wing personalities (eg, Soane Uhila) as left-wing elected officials (eg, Donald Mercier).

The 5 May 2002 election of Jacques Chirac as president of the French Republic facilitated the reelection of the RPR member of parliament of Wallis and Futuna. At the time of the parliamentary elections in June, outgoing Deputy Victor Brial was opposed by four other candidates. His two main opponents (Soane Uhila and Kamilo Gata) did not come forward as candidates, but they supported Penisio Tialetagi, a tradesman whose campaign speech privileged the per- 
sonalization of the ("anti-Brialism") debate. Brial, the candidate of the Union pour la Majorité Presidentielle (UMP), benefited in the second ballot from the partial transfer of Apeleto Likuvalu's votes, although he only won by 58 votes. For the first time, Gaston Lutui, a Wallisian known for his very diverse political career, came forward as candidate for the National Front (FN), an extreme right-wing national party. However, he did not manage to capitalize on the 492 votes that had gone to the national leader of this party at the time of the presidential election.

With regard to New Caledonia, the political authorities of Wallis and Futuna consider that the expatriate community must be especially careful and discrete. Under the care of the Rassemblement Démocratique Océanien (RDO), a party affiliated to the Front de Libération Nationale Kanak Socialiste (FLNKS), and with the participation of a socialist party executive from France, a day of reflection in August 200I brought together about sixty young Caledonians of Wallisian and Futunian origin. On I I October, about fifteen Caledonian pupils of Wallisian and Futunian origin destroyed the office of the headmaster of a Catholic technical school in Bourail. Indeed, at the end of August abusive graffiti by young people from a nearby tribe had called for the departure of this community. The culprits were not punished. Thanks to the arrival of Wallis and Futuna's senator, calm returned after a customary ceremony of forgiveness.

On I 3 November 200I, another problem arose in Saint-Louis: young Wallisian and Futunians set up road blocks following the previous day's stoning by Melanesians of a school bus bringing Polynesian children back to the Wallisian and Futunian hamlet of Ave Maria. This dispute worsened on ro December when several dwellings were set on fire, and inhabitants of Ave Maria and members of the Melanesian tribe of Saint-Louis were injured by gunfire. The long-dormant problem erupted following a rapid increase in the population of Ave Maria and with the appearance of a gang of idle and violent youths on the Saint-Louis side. On 3 February 2002, young Jean-Marie Goyetta died as a result of his wounds. On Io June, a thirty-six-year-old Wallisian, Petelo Motuku, was killed by a sniper as he was setting off for work in his car. Paradoxically, this new drama reduced the tension, and the high commissioner then managed to set up the mediation system greatly desired by the various communities. This serious business had few direct effects on Wallis and Futuna, but it accentuated the unease felt by expatriate Wallisians and Futunians in New Caledonia.

Administratively, the recurring debate on the evolution of the statute of I96I was kept alive by Senator Robert Laufoaulu and the state services. Indeed, the French government's desire was to give the elected officials a sense of responsibility on all levels, and more particularly to support greater autonomy for the three French political entities located in the South Pacific. The statute problem came up in the context of a debate about the place of the traditional chieftaincy in institutions, and also concerning the choice of competencies to be transferred. 
The economy of Wallis and Futuna still depends on direct or indirect transfers from France. In July 200I, the multisector guaranteed minimum wage was raised to FCFP 70,000 , which is much higher than in other countries in the region, yet less than that paid in France. In this regard, the president of the territorial parliament noted that there was "a change of mentality. Wallisians are gradually changing their way of life, their eating habits, their dress, and also their way of thinking. There is now a lot of demand on behalf of the population, which is very new" (Te Fenua Fo'ou, no. 292).

A third merchant ship now brings freight to Mata-Utu. Operated by the Sofrana company, the one-hundredsix-meter-long Sofrana Bligh makes a three-week run starting in New Zealand and calling at Tonga, Samoa, Wallis, and finally Futuna.

The problem of a special interisland ferry service is still unresolved. The chieftaincies of Futuna wanted a financial arrangement based on 9 percent participation for each of the three districts, and 24 percent for the territory, with private shareholders holding 49 percent of the capital. The state imposed an arrangement based on a 5 I percent participation of the territory supplemented by 5 percent participation per district.

The Société Industrielle of Wallis and Futuna, the only real processing plant specializing in the manufacture of sheet metal and aluminum joinery, asked for an increase of 20 percent on customs taxes in its sphere of activity.

Tourism remains underdeveloped, although thirty-six sailing ships anchored in the territory in $200 \mathrm{I}$, with only seventeen flying the French flag. On average, stopovers are five days. In January 2002, reinforcement work and a hundred-meter extension of the runway of Hihifo international airport were completed so that the island could receive A320 airbuses.

There were two noteworthy cultural exhibitions in July 200I. One was devoted to the individuals who were influential during Wallis and Futuna's first forty years as an overseas territory; the other commemorated eighty years of local philately. At the same time, various cultural events emphasized the significant Wallisian and Futunian community of New Caledonia, which sometimes led to sharp reactions from certain Melanesian pro-independence political leaders. On one occasion, sixty-three Futunian dancers and craftsmen went to Noumea and an exhibition catalogue, covering 3,000 years of history, took stock of the prehistoric period in Wallis and Futuna.

On $8 \mathrm{March}$, the editor in chief of the weekly Te Fenua Fo'ou was called to a hearing by the lavelua (king), Tomasi Kulimoetoke. As the king refused the editor's right to evoke the follow-up to the Make Pilioko affair, his interpreter declared that "if the newspaper continued to work in this way, the Lavelua would have the newspaper shut down." The following week, the puluiuvea (customary minister of the police force) ordered the equipment belonging to the manager, Michel Bodineau, confiscated or destroyed. Bodineau managed to publish a last edition (no. 326) in Noumea before declaring his company bankrupt. The headline of the last editorial read: “Absolute Monarchy 
or French Banana Republic?” In Wallis, 700 copies of the headline were distributed and in New Caledonia, 800 copies.

In April, the Oceania Customs Organization was the first international conference to be hosted by Mata-Utu. Regarding religion, a noteworthy event was the translation of the New Testament (Ko le Tausifo'ou) into Futunian.

Groups of affiliated trade unions of France continued to train their members on the other side of the world. The Force Ouvrière trade union sent a training officer for a week in August 200I. In sports, men's cricket (kilikiti) is again in fashion in the district of Mua.
Lastly, on the customary level, in September 200 I Soane Patita Suve became Tui Toafa, that is, the new chief of the village of Mala'e. In October, Mikaele Holoia became Utumaka, the chief of one of the halves of Vailala village. In November, Keleto Lakalaka again became Tui Uvea, chief of Te'esi. In January 2002, Petelo Ponoso was established as Eva, the title of the chief of Utufua.

FRÉDÉRIC ANGLEVIEL

\section{References}

Te Fenua Fo'ou. Weekly. 